\title{
DIRECT AND INDIRECT SPEECH IN STRAIGHT-TALKING ISRAELI
}

\author{
GHIL'AD ZUCKERMANN
}

The University of Queensland St Lucia QLD 4072

Australia

gz208@cam.ac.uk

\begin{abstract}
Israeli is currently one of the official languages of the State of Israel. It is a fusional synthetic language, with non-concatenative discontinuous morphemes realised by vowel infixation. This typological paper demonstrates that there is a clear distinction in Israeli between direct and indirect speech. The indirect speech report, which is a subset of complement clauses, is characterized by a shift in person, spatial and temporal deixis. However, unlike in English, the verbs usually do not undergo a tense shift. Israeli has various lexicalized direct speech reports. By and large, Israeli reported speech constructions reflect Yiddish and Standard Average European patterns, often enhancing a suitable pre-existent Hebrew construction.
\end{abstract}

Keywords: Hebrew, reported speech, Yiddish, lexical derivation, Congruence Principle

\section{Introduction}

\subsection{General information}

Israeli (Zuckermann 1999; 2006b, a.k.a. "Modern Hebrew") is currently one of the official languages - with Arabic and English - of the State of Israel, established in 1948 on $20,770 \mathrm{~km}^{2}$ (0.22 of Hungary) in the Middle East. It is spoken to varying degrees of fluency by its 7,026,000 citizens (as of May 2006) - as a mother tongue by most Jews (whose total number exceeds 5.6 million), and as a second language by Muslims 
(Arabic-speakers), Christians (e.g., Russian- and Arabic-speakers), Druze (Arabic-speakers) and others.

\subsection{Grammatical profile}

Israeli is a fusional synthetic language, with non-concatenative discontinuous morphemes realised by vowel infixation. Compare (1) and (2), both formed from the root p.t.r., but fitted into two distinct verb-templates:

(1) נפטר (1)

niftár

pass.away:3msg.past

'(he) passed away'

התפוטרנו (2)

hitputárnu

resign:1pl.past: "coercive"

"We "resigned" (implying that we were encouraged to do so; had we not done so, we would have been fired anyway).'

Israeli is a head-marking language. It is nominative-accusative at the syntactic level and partially also at the morphological level. As opposed to Biblical Hebrew - whose constituent order is $\mathrm{VAO}(\mathrm{E}) / \mathrm{VS}(\mathrm{E})$ - but like Standard Average European and English, the usual constituent order of Israeli is $\mathrm{AVO}(\mathrm{E}) / \mathrm{SV}(\mathrm{E})$. Thus, where there is no case marking, one can resort to the constituent order.

The main clause in Israeli consists of (a) clause-initial peripheral markers, e.g., discourse markers; (b) NP(s) or complement clause(s); (c) a predicate - either verbal, copular or verbless; (d) clause-final peripheral elements, e.g., discourse markers. The only obligatory element is the predicate, e.g., higáti 'arrive:1sg.past'.

Sentences (3), (4) and (5) are examples of a verbal, copular and verbless clause, respectively:

הילדה אכלה תפוח. (3)

$[\text { ha-yaldá }]_{\mathrm{A}}[\text { akhl-á }]_{\mathrm{V}} \quad[\text { tapúakh }]_{\mathrm{O}}$

$[\text { def-girl }]_{\mathrm{A}} \quad[\text { eat:3past-fsg }]_{\mathrm{V}}[\text { apple }]_{\mathrm{O}}$

'The girl ate an apple.'

Acta Linguistica Hungarica 53, 2006 
הילדה הזאת היא אחות שלי. (4at)

[ha-yaldá ha-zòt $]_{\mathrm{CS}} \quad[\text { hi }]_{\mathrm{COP}} \quad[\text { akhót shel-ì }]_{\mathrm{CC}}$ [def-girl def-prox.fsg $]_{\mathrm{CS}}[\mathrm{cop}: \mathrm{fsg}]_{\mathrm{COP}}[\text { sister gen-1sg }]_{\mathrm{CC}}$

'This girl is my sister.'

הילדה חכמה. (5) (5)

[ha-yaldá $]_{\mathrm{VCS}}[$ khakham-á] $\mathrm{VCC}$

$[\text { def-girl }]_{\mathrm{VCS}} \quad[\text { clever-f }]_{\mathrm{VCC}}$

'The girl is clever.'

There are various types of subordinate clause, e.g., adverbial (denoting comparison, time, place, condition, concession, reason, result, goal, state), adjectival/relative, and nominal/ complement. By and large, these follow the Standard Average European profile. Indirect speech report fits into the overall system of complement clauses - see section $\mathbf{3 . 1}$.

\section{Speech report constructions}

\subsection{The DSR/ISR distinction}

Due to (inter alia) the lack of evidentials in the language, Israeli does not possess any monoclausal speech report construction. It has a clear distinction between multiclausal direct speech report (henceforth, DSR) and multiclausal indirect speech report (henceforth, ISR), the ISR generally being more common than DSR.

Distinguishing features characterizing ISR:

(i) Shift in person deixis, e.g., $2>1$

(ii) Shift in spatial and temporal deixis, e.g., 'today' > 'that day', also spatial demonstratives, e.g., 'this' > 'that'

(iii) Obligatory presence of a complementizer immediately before the speech report, unless the speech report is of the 'infinitive' (iv) or interrogative type (v)

(iv) In report of commands: imperative/future verb > "infinitive" (tenseless verb, commonly referred to in Israeli grammar as "infinitive", thus, henceforth, INF)

(v) In report of questions: interrogative-less yes/no question $>i m$ (lit. 'if') or ha-im (lit. 'INTER-if') 'whether' immediately before the indirect question 
Unlike in English, verbs do not undergo a tense shift. The future tense in a speech act in the past does not become future-in-the-past in ISR (see (16)); unlike English (cf. would), Israeli does not have a form of futurein-the-past. Similarly, present tense in a speech act in the past usually does not become past in ISR (see (9)).

Like in English, in indirect " $w h$-questions", the interrogative remains the same. Unlike in English, there is no change in constituent order (see $(15)-(16))$.

Distinguishing features characterizing DSR:

(i) Special intonation contour, tending to be mimetic

(ii) Possible intonational break before the DSR

(iii) Possible absence of a reporting verb

(iv) Possible discontinuity of the DSR

(v) Possible use of a vocative particle

(vi) In writing: presence of quotation marks, as well as exclamation/ question mark

Sentences (6) and (7) demonstrate the shift in person deixis:

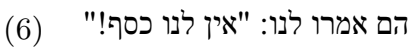

hem amr-ú l-anù [én $\quad$ l-anù késef $]_{\mathrm{DSR}}$

3mpl say:3past-pl dat-1pl [exis.cop:neg dat-1pl money]

'They told us: "We have no money!"'

הם אמרו לנו שאין להם כסף. (7) (7)

hem amr-ú l-anù $\langle\text { she-én l-ahèm késef }\rangle_{\text {ISR }}$

3mpl say:3past-pl dat-1pl 〈comp-exis.cop:neg dat-3mpl money〉

'They told us that they had no money.'

Sentences (8) and (9) demonstrate the lack of tense shift in verbs:

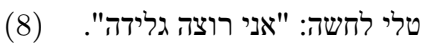

Tali lakhash-á [anì rotsá glída $]_{\mathrm{DSR}}$

Tali whisper:3past-fsg [1sg want:fsg.pres ice.cream]

'Tali whispered: "I want ice cream!"'

טלי לחשה שהיא רוצה גלידה. (9asheá)
Tali lakhash-á $\quad\langle\text { she-hì rotsá glída }\rangle_{\text {ISR }}$
Tali whisper:3past-fsg 〈comp-3fsg want:fsg.pres ice.cream〉
'Tali whispered that she wanted ice cream.' 
Note that - in contrast to the English translation - the verb 'want' is in the present tense in both sentences.

\subsection{Exclamative and vocative DSR}

Obviously, not every DSR is transformable into an ISR:

כש"גילו" למדלן אולברייט שהיא יהודייה, היא צווחה: "אוי וויי!" (10) (stadt)

k-she-"gil-ú" le-mádlen ólbrayt 〈she-hí yehudi-yá $\rangle_{\text {ISR }}$

when-comp- "reveal" :past-3pl to-Madeleine Albright 〈comp-3fsg Jewish-fsg

hi tsavkh-á [óy véy! $]_{\text {DSR }}$

3fsg scream:3past-fsg [Oy vey]

"When it was "revealed" to Madeleine Albright that she was Jewish, she screamed:

"Oy vey!",

ISR cannot convey the associations accompanying a DSR vocative particle:

הוא צעק עליה: "תפסיקי לנדנד, יא נודניקית!" (11)

hu tsaák al-èa:

3msg shout:3msg.past on-3fsg

[tafsík-i le-nadnéd, ya núdnik-it!] DSR

[stop:2fut/imp-fsg inf-bother voc:derog pest-fsg]

'He shouted at her: "Stop bothering, ya pest!"'

The vocative particle ya (cf. archaic English $O$, as well as contemporary colloquial (Antipodean) English ya, or y', from you) is currently derogatory in the sense that it only precedes derogatory NPs. This particle can be traced back to the vocative exclamatory Arabic particle [ya:]. Initially, Israeli ya - just like in Arabic - was not derogatory see the Israeli songs ya mishlati ' $\mathrm{O}$ my fortified cliff' and ya khabíbi ' $\mathrm{O}$ my dear'. However, native Israeli-speakers are aware of the Arabic etymon and - perhaps due to the negative (e.g., terroristic) associations of Arabic among Israelis - ya underwent semantic - or rather pragmatic narrowing: pejoration.

\subsection{ISR complementizer}

As shown in (7) and (9), ISR usually uses the common Israeli complementizer she [Je] 'that', which - just like English that-also acts as a 
relativizer. She- 'that' can be traced back to the Hebrew complementizer she- 'that', which derives from the Hebrew relativizer she- 'that'. One etymological analysis is that she- is a shortened form of the Hebrew relativizer 'asher 'that', which is related to Akkadian 'ashru 'place' (cf. Semitic *'athar).

Instead of using the she-complementizer, a more formal Israeli writer could use the rare complementizer $k i$ 'that', which derives from the Hebrew complementizer $k \bar{l}$ 'that', from $k i$ 'because'. Consider the following minimal pair:

הנאשם הצהיר כי הוא חף מפשע. (12)

ha-neeshám hitsír $\quad\langle\mathbf{k i} \text { hu khaf mi-pésha }\rangle_{\text {ISR }}$

def-accused:msg declare:3msg.past 〈comp 3msg clean from-crime〉

'The accused declared that he was innocent.'

הנאשם זוכה כי הוא חף מפשע. (13)

ha-neeshám zuká [ki hu khaf mi-pésha $]_{\text {CAUS }}$

def-accused:msg acquit:3msg.past:pass [caus 3msg clean from-crime]

'The accused was acquitted because he was innocent.'

Whereas in (12) $k i$ introduces an ISR, in (13) it introduces a causal clause. But such versatility can easily result in ambiguity:

הן לא סיפרו לי כי כבר הסבירו את זה. (14)

hen lo sipr-ú l-i

3fpl neg tell:3past-pl dat-1sg

$\langle\mathbf{k i} \quad \text { kvar hisbír-u et ze }\rangle_{\text {ISR/CAUS }}$

〈comp/caus already explain:3past-pl acc prox.msg)

'They (f) did not tell me that it had already been explained.'

or 'They (f) did not tell me (about it) because it had already been explained.'

Thus, $k i$ is often avoided even by Israelis attempting to write in a highflown manner. As opposed to she-, I categorize $k i$ as a prescriptive complementizer tout court. That said, some French-speaking immigrants to Israel use the complemetizer $k i$ less rarely than other Israelis because of the serendipitous phonetic similarity to the French complementizer que 'that' — cf. Zuckermann (2006b). 


\subsection{Direct and indirect questions}

Unlike in English, Israeli indirect questions demonstrate neither a shift in verb tense nor a change in constituent order. Thus, besides the distinct intonation, the only difference between (15) and (16) is the pronominal suffix used with the genitive shel 'of' (i.e., the only shift is in person):

הוא שאל אותה: "מתי ההורים שלך יגיעו?" (15)

hu shaál ot-à

3msg ask:3msg.past dat-3fsg

[matáy ha-hor-ím shel-àkh yagí-u $]_{\mathrm{DSR}}$

[when def-parent-mpl gen-2fsg arrive:3fut-pl]

'He asked her: "When will your parents arrive?",

הוא שאל אותה מתי ההורים שלה יגיעו. (16)

hu shaál ot-à

3msg ask:3msg.past dat-3fsg

$\langle\text { matáy ha-hor-ím shel-à yagí-u }\rangle_{\text {ISR }}$

$\langle$ when def-parent-mpl gen-3fsg arrive:3fut-pl $\rangle$

'He asked her when her parents would arrive.'

Thus, one may regard the indirect question as a semi-direct speech report.

Although Standard Average European (often via Yiddish) is undoubtedly an important source for Israeli reported speech, this indirect question construction seems to have already existed in Hebrew too. Consider, for example, Biblical Hebrew lo noda' $\langle$ mi hikkáhu $\rangle$ 'it be not known 〈who hath slain him〉' (Deuteronomy 21:1). Such multiple causation corresponds with the Congruence Principle: if a feature exists in more than one contributor, it is more likely to persist in the target language (see Zuckermann 2003).

\subsection{Direct and indirect commands: infinitive ISR}

ISR can lack a complementizer and instead begin with a tenseless verb, commonly referred to as "infinitive".

המפקדת הורתה: "תהיו כאן תוך שבע דקות!" (17)

ha-mefakéd-et hortá [tiyú kan tokh shéva dak-ót $]_{\mathrm{DSR}}$ def-commander-fsg order:3fsg.past [be:2pl-fut/imp here within seven minute-pl]

'The commander (f) ordered: "Be here within seven minutes!" 
המפקדת הורתה להיות שם תוך שבע דקות. (18)

ha-mefakéd-et hortá $\quad\langle\text { il-yót sham tokh shéva dak-ót }\rangle_{\text {ISR }}$

def-commander-fsg order:3fsg.past 〈inf-be there within seven minute-pl〉

'The commander (f) ordered to be back there within seven minutes.'

DSR has the capacity to be more nuanced than ISR. Thus, one ISR can be parallel to several distinct DSRs. For example, (18) can be the ISR not only of (17) but also of (19), which includes a semantic future perfect, realised morphologically in colloquial Israeli by the past:

המפקדת הורתה: "תוך שבע דקות הייתם כאן!" (19)

ha-mefakéd-et hortá [tokh shéva dak-ót haítem kan] def-commander-fsg order:3fsg.past [within seven minute-pl be:2mpl.past here]

'The commander (f) ordered: "Within seven minutes, you will have arrived back here!"'

\section{Syntactic role of speech report content}

\subsection{ISR versus complement clause}

Israeli ISR conforms to complement clause structure. The following three sentences, which constitute a continuum, demonstrate that ISR is a subset of complementation:

אני יודע שהיא יפה. (20)

anì yodéa $\quad\langle\text { she-hì yaf-á }\rangle_{\mathrm{COMP}}$

1sg know:msg.pres 〈comp-3fsg beautiful-fsg

'I know that she is beautiful.'

שמעתי שהיא יפה. (21) (21)

shamá-ti $\quad\langle\text { she-hì yaf-á }\rangle_{\mathrm{COMP} / \text { ISR }}$

hear:past-1sg 〈comp-3fsg beautiful-fsg〉

'I heard that she is beautiful.' (a general hearsay, not referring to a specific speech act) or 'I heard that she was beautiful.' (a specific speech act)

אמרתי לה שהיא יפה. (22)

amár-ti l-a $\quad\langle\text { she-hì yaf-á }\rangle_{\text {ISR }}$

say:past-1sg dat-3fsg 〈comp-3fsg beautiful-fsg

'I told her that she was beautiful.'

A speech report can be referred to en bloc using the proximal demonstrative ze 'this'. Thus, (23) could be a retort to (22):

Acta Linguistica Hungarica 53, 2006 
אתה אמרת את זה ברצינות? (23)

atá amár-ta et ze bi-rtsinút?

2msg say:past-2msg acc prox.msg in-seriousness

'Did you say that seriously?'

\subsection{Reporting verbs}

The reporting verb usually appears before the speech report, although in literary style, it can follow the speech report either immediately or after the A, i.e., either 'Go away!', said the child or 'Go away!', the child said, the former being of a higher register.

The most common verb used in both DSRs and ISRs is the transitive amár 'say:3msg.past'. This verb has suppletive future and infinitive forms: yagíd 'say:3msg.fut' and le-hagíd 'inf-say' respectively. That said, the future and infinitive forms yomár and l-omár exist but, unlike in Hebrew, they are not normally used in Israeli.

As previously seen, Israeli has a plethora of other reporting verbs (see Table 1, overleaf).

Moreover, colloquial Israeli often employs asá, lit. 'do:3msg.past', as a reporting verb:

$$
\begin{aligned}
& \text { אז המהבולה הזאת עושה לי: "צ'מע קטע! אני מה זה בדאון" } \\
& \text { אז עשיתי לה: "למה מה קרה? משה לי מת? "צע קטיל מאי לסרט, תום אומר שזה פצצות לגבות!" }
\end{aligned}
$$

$$
\begin{array}{ll}
\text { az ha-mahabúl-a ha-zòt osá l-i } \\
\text { so def-fool-fsg def-prox.fsg do:fsgpres dat-1sg }
\end{array}
$$$$
\text { [chmá kèta, anì má ze be-dàwn }]_{\mathrm{DSR}}
$$

[hear:2msgimp fragment 1sg what prox.msg in-down]

$$
\text { az asíti l-a [làma má karà? mí met?, }
$$

so do:1sgpast dat-3fsg why what happen:3msg.past who die:3msg.past

bói l-a-séret, tom omér

come:2fsg.imp to-def-film Tom say:msg.pres

$\left.\langle\text { she-zé } \quad \text { ptsats-ót l-a-gab-ót }\rangle_{\mathrm{ISR}}\right]_{\mathrm{DSR}}$ $\langle$ comp-proxmsg bomb-fpl to-def-eyebrow-fpl $\rangle]$

"So that idiot (f) goes: "Listen, I'm really down". So I was like: "What the hell? What's your deal? Come to the film, Tom says it's wicked.",

Literally: 'So this idiot (f) does to me: "Hear a fragment, I'm what in a down!". So I did to her: "Why, what happened? Who died? Come to the film, Tom says that this is bombs to the eyebrows!".' 
Table 1

Classification of Reporting Verbs

\begin{tabular}{|c|c|c|c|}
\hline Verb & Transitivity & Translation & Semantic Class \\
\hline amár & $\operatorname{tr}$ & say & saying \\
\hline sipér & $\operatorname{tr}$ & tell, recount (cf. safár 'count') & saying \\
\hline hodía & $\operatorname{tr}$ & announce, notify & saying \\
\hline yidéa & $\operatorname{tr}(\mathrm{O}=$ addressee $)$ & inform & saying \\
\hline taán & $\operatorname{tr}$ & claim & saying \\
\hline hitsír & $\operatorname{tr}$ & declare & saying \\
\hline hikhríz & $\operatorname{tr}$ & proclaim & saying \\
\hline tsaák & $\operatorname{tr}$ & shout & saying + speech manner \\
\hline lakhásh & $\operatorname{tr}$ & whisper & saying + speech manner \\
\hline milmél & $\operatorname{tr}$ & mutter & saying + speech manner \\
\hline shar & $\mathrm{amb}$ & $\operatorname{sing}$ & saying + speech manner \\
\hline gimgém & intr & stutter & saying + speech manner \\
\hline tsavákh & $\operatorname{tr}$ & scream & saying + speech manner \\
\hline tsarákh & $\operatorname{tr}$ & yell & saying + speech manner \\
\hline zaák & $\operatorname{tr}$ & cry out & saying + speech manner \\
\hline tsahál & intr & rejoice & saying + speech manner \\
\hline yilél & intr & howl & saying + speech manner \\
\hline yibév & intr & wail & saying + speech manner \\
\hline tsikhkék & intr & giggle & saying + speech manner \\
\hline shaág & intr & roar & saying + speech manner \\
\hline teér & $\operatorname{tr}$ & describe & proposition \\
\hline hisbír & $\operatorname{tr}$ & explain & proposition \\
\hline tsién & $\operatorname{tr}$ & mention & proposition \\
\hline hizkír & $\operatorname{tr}$ & mention & proposition \\
\hline heelíl & $\operatorname{tr}$ & allege & proposition \\
\hline heíd & intr & testify & proposition \\
\hline diveákh & $\operatorname{tr}$ & report & report \\
\hline perét & $\operatorname{tr}$ & detail & report \\
\hline hosif & $\operatorname{tr}$ & add & report \\
\hline hivtíakh & $\operatorname{tr}$ & promise & promise \\
\hline iyém & intr & threaten & promise \\
\hline hizhír & $\operatorname{tr}(\mathrm{O}=$ addressee $)$ & warn & promise \\
\hline
\end{tabular}

Acta Linguistica Hungarica 53, 2006 
Table 1 (cont.)

\begin{tabular}{|c|c|c|c|}
\hline Verb & Transitivity & Translation & Semantic Class \\
\hline makhá al & intr & protest about & complaint \\
\hline hitlonén & intr & complain & complaint \\
\hline kitér & intr & $\begin{array}{l}\text { whine, whinge (cf. Polish Yiddish } \\
\text { kútar 'male cat, whiner') }\end{array}$ & complaint \\
\hline kavál al & intr & complain about (high register) & complaint \\
\hline hitonén & intr & complain & complaint \\
\hline tsivá & $\operatorname{tr}(\mathrm{O}=$ addressee $)$ & order & command \\
\hline horá & intr & order & command \\
\hline pakád & $\operatorname{tr}(\mathrm{O}=$ addressee $)$ & command & command \\
\hline amád al kakh & intr & insist & command \\
\hline hiftsír (be) & intr & urge (high register) & requesting \\
\hline bikésh (mi) & $\operatorname{tr}$ & request (from) & requesting \\
\hline darásh (mi) & $\operatorname{tr}$ & demand (from) & requesting \\
\hline shaál & $\operatorname{tr}(\mathrm{O}=$ addressee $)$ & ask & asking \\
\hline tahá & intr & wonder & asking \\
\hline aná & intr & answer & answering \\
\hline heshív & intr & reply & answering \\
\hline hegív & intr & react & answering \\
\hline gaár & intr & scold & rebuke \\
\hline nazáf (be) & intr & reprimand & rebuke \\
\hline hokhíakh & $\operatorname{tr}(\mathrm{O}=$ addressee $)$ & reprove & rebuke \\
\hline odéd & $\operatorname{tr}(\mathrm{O}=$ addressee $)$ & encourage & encouragement \\
\hline shamá & $\operatorname{tr}$ & hear & hearing \\
\hline
\end{tabular}

\subsection{DSR without a reporting verb}

Whereas a reporting verb is obligatory in ISR, it is possible to have a DSR without it:

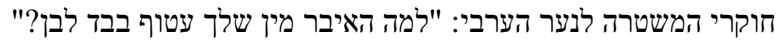

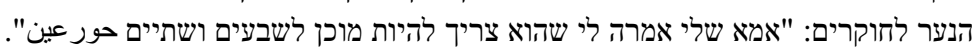
khokr-éy
ha-mishtará l-a-náar
ha-arav-1́:

investigator-mpl:constr def-police dat-def-teenager def-Arab-msg

[láma ha-evàr mín shel-khà atúf be-bàd laván?] $\mathrm{DSR}$

[why def-organ sex gen-2msg wrap:msg.pres:pass in-cloth white]

ha-náar l-a-khokr-ím:

def-teenager dat-def-investigator-mpl 
[íma shl-ì amr-á l-ì

[mother gen-1sg say:3past-fsg dat-1sg

〈she-hù tsaríkh li-yót mukhán

<comp-3msg need:msg.pres inf-be ready:msgpres:pass

le-shivím ve-shtáim $\hbar u: r$ \{ir $\left.n\rangle_{\mathrm{ISR}}\right]_{\mathrm{DSR}}$

to-seventy and-two $\hbar u: r\{i: n\rangle]$

"The police investigators to the Arab teenager: "Why are your genitals wrapped with white cloth?" The teenager to the investigators: "My mother told me that

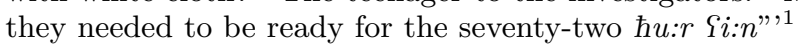

\section{Direct speech report as a basis for lexical derivations}

Israeli has many NPs which are lexicalized DSRs, usually couched in the first person:

ה"אני מאמין" של מבקר המדינה הנכנס: מלחמה עיקשת בשחיתות. (26) (20aka

ha-[aní maamín $]_{\mathrm{NP}}$ shel mevakér ha-mdiná ha-nikhnás:

def-[1sg believe:msg.pres] gen comptroller def-state def-enter:msg.pres

milkhamá ikésh-et b-a-shkhitút

war:fsg stubborn-fsg in-def-corruption

'The incoming State Comptroller's credo: unrelenting war on corruption.'

הח"כ יצא ב"אני מאשים" נגד הממשלה. (27)

ha-khá-k yatsá

def-M(ember)-K(nesset) come.out:3msg.past

be-[aní maashím $]_{\mathrm{NP}}$ néged ha-m(e)mshalá

in-1sg accuse:msg.pres against def-government

'The MK (Member of Knesset (Israeli Parliament)) came out with a J'accuse against the government.'

${ }^{1}$ Seventy-two حور [hu:r Si:n] are promised to the faithful martyrs in Suras 44:54 and $52: 20$ of the Koran. Muslims believe that these are "dark, wide-eyed (maidens)", virgins. However, Luxenberg (2000) suggests that $\hbar u: r$ Y $i: n$ are actually "white (grapes), jewels (of crystal)". In other words, Muslim martyrs will not get virgins but sultanas(!), the latter with the meaning of white raisins/grapes. Syriac [ћurr] 'white (fpl)' is associated with 'raisin' — cf. Zuckermann (2006a). If this alternative interpretation is true, or rather, if one can convince fundamentalist Muslims that it is true, it has the potential to change the course of history, at least in cases like the above true story of a Palestinian teenager caught in Israel just before attempting a suicide-bombing.

Acta Linguistica Hungarica 53, 2006 
Consider also the following:

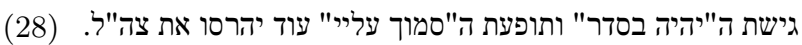

gishá-t ha-[yiyé be-séder]

attitude-constr def-[be:3msg.fut in-order]

ve-tofaá-t ha-[smókh al-áy]

and-phenomenon-constr def-[trust:2msg.imp on-1sg]

od yaharsú et tsáhal ${ }^{2}$

yet destroy:3pl.fut acc IDF

"The "she'll be right" attitude and the "trust me!" phenomenon may destroy the IDF (Israel Defence Forces).'

\section{Functional, stylistic and discourse preferences}

DSR is common in Israeli in informal speech or story-telling, and is often employed in jokes; in-your-face Israelis often use (sometimes macabre) self-deprecating humour:

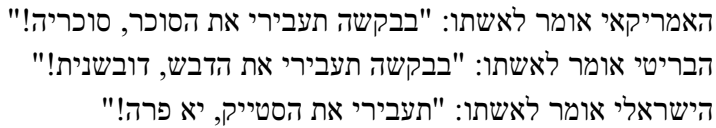

"The American tells his wife: "Would you pass the sugar, sugar!". The Briton tells his wife: "Would you pass the honey, honey!". The Israeli tells his wife: "Pass the steak, ya cow!",

${ }^{2}$ Acronym of tsvá ha-haganá le-israél 'Israel Defence Forces'. 
The following passage employs both DSR and ISR. DSR is employed for immediacy and engaging effect, including a couple of serendipitous $e x$ postfacto puns. ISR conveys important new information but since the specific form of the speech act is not crucial, it is backgrounded:

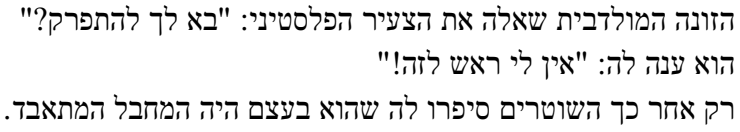

'The Moldavian prostitute asked the Palestinian youth: "Do you feel like getting off?" (lit. "Does it come to you to disassemble?"). He replied: "I'm not in the mood!" (lit. "I don't have a head for it!"). Only later did the policemen tell her that he actually was the suicide bomber.'

\section{Concluding remarks}

There is a clear distinction in Israeli between direct and indirect speech. The indirect speech report, which is a subset of complement clauses, is characterized by a shift in person, spatial and temporal deixis. However, unlike in English, the verbs usually do not undergo a tense shift. Israeli has various lexicalized direct speech reports. By and large, Israeli reported speech constructions reflect Yiddish and Standard Average European patterns, often enhancing a suitable pre-existent Hebrew construction.

\section{Abbreviations}

$1=1$ st person; $2=2$ nd person; $3=3$ rd person; $\mathrm{A}=$ transitive subject; acc $=$ accusative; $\mathrm{amb}=$ ambitransitive CAUS/caus = causal; $\mathrm{CC}=$ copula complement; 
comp $=$ complement(izer) $;$ constr $=$ construct-state COP $/$ cop $=$ copula $; \mathrm{CS}=$ copula subject; dat $=$ dative; def $=$ definite; $\operatorname{derog}=$ derogatory; DSR $=$ direct speech report; $\mathrm{E}=$ extended intransitive; exis $=$ existential $\mathrm{f}=$ feminine; fut $=$ future; gen $=$ genitive; $\mathrm{imp}=$ imperative; INF $/$ inf = infinitive; INTER = interrogative; intr = intransitive; $\mathrm{ISR}=$ indirect speech report; $\mathrm{m}=$ masculine; $\mathrm{neg}=$ negator $/$ negative; $\mathrm{NP}=$ noun phrase; $\mathrm{O}=$ transitive object; pass = passive; $\mathrm{pl}=$ plural; poss $=$ possessive; pres $=$ present; $\operatorname{prox}=$ proximal demonstrative; $\mathrm{S}=$ intransitive subject; $\mathrm{sg}=$ singular; $\operatorname{tr}=$ transitive; $\mathrm{V}=$ verb; $\mathrm{VCC}=$ verbless clause complement; $\mathrm{VCS}=$ verbless clause subject; voc $=$ vocative

\section{References}

Luxenberg, Christoph 2000. Die syro-aramäische Lesart des Koran. Ein Beitrag zur Entschlüsselung der Koransprache. Das Arabische Buch, Berlin.

Zuckermann, Ghil'ad 1999. Review article of Nakdimon Shabbethay Doniach and Ahuvia Kahane (eds), The Oxford English-Hebrew Dictionary. In: International Journal of Lexicography $12: 325-46$.

Zuckermann, Ghil'ad 2003. Language contact and lexical enrichment in Israeli Hebrew. Palgrave Macmillan, London.

Zuckermann, Ghil'ad 2006a. haivrít kemítos [Hebrew as myth]. Am Oved, Tel Aviv.

Zuckermann, Ghil'ad 2006b. A new vision for Israeli Hebrew: Theoretical and practical implications of analysing Israel's main language as a semi-engineered SemitoEuropean hybrid language. In: Journal of Modern Jewish Studies 5:57-71. 